\title{
Humanization of the hospital: participatory construction of knowledge and practices on care and ambience*
}

\author{
Humanização hospitalar: construção coletiva de saberes e práticas \\ de acolhimento e ambiência \\ Humanización de hospitales: construcción colectiva de saberes y prácticas \\ de acogida y ambientación
}

How to cite this article:

Salvati CO, Gomes CA, Haeffner LSB, Marchiori MRCT, Silveira RS, Backes DS. Humanization of the hospital: participatory construction of knowledge and practices on care and ambience. Rev Esc Enferm USP. 2021;55:e20200058. doi: https://doi.org/10.1590/1980-220X-REEUSP-2020-0058

\section{Caroline de Oliveira Salvati ${ }^{1}$ \\ Carine Alves Gomes ${ }^{2}$ \\ Leris Salete Bonfanti Haeffner ${ }^{1}$ \\ D Mara Regina Caino Teixeira Marchiori ${ }^{3}$ \\ Rosemary Silva da Silveira ${ }^{1}$ \\ Dirce Stein Backes ${ }^{3}$}

* Extacted from disseratation "Acolhimento e Ambiência: dispositivos para humanização hospitalar", Programa de Mestrado em Ciências da Saúde e da Vida, Universidade Franciscana, Santa Maria, RS, Brazil. 2019

${ }^{1}$ Universidade Federal do Rio Grande, Rio Grande, RS, Brazil.

${ }^{2}$ Hospital São Francisco de Assis, Santa Maria, RS, Brazil.

${ }^{3}$ Universidade Franciscana, Santa Maria, RS, Brazil.

\begin{abstract}
Objective: To identify and implement care and ambience strategies, with a view to hospital humanization. Method: Action-research study, whose investigation process occurred between January and March 2019, with the participation of employees in strategic functions of a medium-sized hospital, through a focus group and strategic focal analysis. The implementation of care and ambience strategies started in May 2019 and remains in progress, with the responsible and multiplying participation of professionals and patients. Results: 18 employees participated in the study. It was found that investigative processes accompanied by practical interventions, especially those related to the promotion of interactive, inclusive, care spaces and the creation of a ludic, attractive and interactive environment favor multi-professional actions, mobilize innovative knowledge and practices, and contribute to the (re)signification of the being and doing of the health professional. Conclusion: Care and ambience, with a view to hospital humanization, include the implementation of strategies designed with the responsible and multiplying participation of all actors (professionals and users) of the hospital. It is important that, in this process, everyone feels they are protagonists of new ways of being, living and doing in health.
\end{abstract}

\section{DESCRIPTORS}

Hospitalization; User Embracement; Humanization of Assistence; Health Facility Environment; Professional-Patient Relations; Occupational Health. 


\section{INTRODUCTION}

The humanization of hospitals is a topic that has been discussed and, in Brazil, it has been promoted by the Ministry of Health since the middle of 2000, with the National Program for Humanization of Hospital Assistance (PNHAH). The objective of this program was to enhance health practices by improving hospital management and infrastructure and increasing dialogue and professional awareness processes. The humanization of hospitals was understood as an ethical process, in which the "other" human was respected and welcomed, motivated by the synergistic ambience and the enhancement of healthy professional relationships. After this path that broadened the possibilities of interaction and participation, and recognizing the realistic and prospective experiences, the Ministry of Health launched, in 2003, the National Humanization Policy HumanizaSUS (PNH). With this approach, the isolated and linear idea of "Program" (with a beginning, middle and end) was overcome by the notion of a health "Policy", with the idea of embracing the human being as a subject-citizenpolitical being and the clinic, in its expanded version, as an integrated and coordinated system ${ }^{(1-4)}$.

In this evolutionary process, the objective of the HumanizaSUS has been to promote affirmative and prospective movements for the consolidation of the SUS. Managers, professionals, and healthcare users participate in this horizontal and transformative movement. This dialogic and participatory relationship focuses on the subjective dimension of health care, which comprises the uniqueness and multidimensionality of human beings and of care, as a complex phenomenon. However, the implementation of humanized hospital care requires more than a health policy; it must be based on ethics and occur in a care environment. This way, humanization is not only concerned with things as they are, but with things as they can be and, especially, as they should be, according to the identification and mobilization of collective intervention strategies ${ }^{(5-6)}$.

Thus, considering the relevance of studies that address the implementation of concrete humanization strategies in hospital institutions, the research question was: How to promote a care and humanizing hospital ambience that considers the uniqueness and the procedural, dynamic and participatory character of the different actors in health care? Based on the above, the objective was to identify and implement care and ambience strategies, with a view to hospital humanization.

\section{METHOD}

\section{Type OF Study}

The action-research method was adopted because it allows the construction and implementation of knowledge and practices, with the participation of collaborators who were engaged both in the investigation process and in the implementation and (re)signification of the practice. The method considers the empirical knowledge, based on the needs identified by the collective subject, in order to find strategies to (re)think and enhance health care settings ${ }^{(7)}$.

\section{Study SETTING}

The study was carried out in a medium-sized Philanthropic Hospital, located in the central region of Rio Grande do Sul. The institution was chosen because it is where the main author works and, mainly, due to the desire of the senior management, who has as one of its strategic goals trying to create a care and humanizing hospital ambience that considers the procedural, dynamic and participatory character of all health care actors.

\section{Population}

The inclusion criteria were: employees of the hospital with more than six months of experience, in different areas and levels of professional training. Employees who were on vacation, medical leave or maternity leave during the data collection period were excluded from the study.

\section{DATA COLLECTION}

The investigation process occurred from January to March 2019, with the participation of 18 employees with strategic roles, that is, professionals who were in a leadership role in different sectors of the institution, as appointed by the direction of the Hospital. Data were collected using the focus group technique ${ }^{(7)}$, through three sequential meetings, held during office hours and on previously agreed days and times.

The implementation of care and ambience strategies began in May 2019 and remains in progress, with the active and multiplying participation of employees and patients. In the intervention process, systematic teamwork activities were developed with the objective of improving living spaces and strengthening the bond between employees and between employees and users, as detailed in the results of this study.

\section{DATA ANALYSIS AND TREATMENT}

Strategic Analysis (SA) was adopted as data analysis technique, considering that it allows the synthesis/analysis of focus groups in a creative and constructive way and enables critical-reflective thinking about humanization in the hospital environment, as proposed in the theoretical framework of this study. This technique is specific for the analysis of data from focus groups and occurs at the same time as data collection, starting in the moment when the moderator and the participants expand and deepen the debates. This method of analysis allows the active interaction of study participants, through strategic proposals. Therefore, it represents a circular, dynamic, and gradual process, as proposed by the technique ${ }^{(7)}$.

\section{ETHICAL ASPECTS}

This study was approved by the Research Ethics Committees of the Hospital and Educational Institution, protocol \#3093319/18. It followed the recommendations of 
Resolution no. 466/12, of the National Health Council, on research with human beings. To maintain the anonymity of the participants, their speeches were identified by numbers $(\mathrm{P} 1, \mathrm{P} 2 \ldots)$, at the suggestion of the employees.

\section{RESULTS}

The investigation process resulted in twelve humanization strategies related to care and hospital ambience. The care strategies listed by the participants and implemented in practice were associated with the need to expand interactive and associative processes with all the subjects in that hospital. All the strategies listed and discussed could be implemented without significant resources or financial investment. Continuing health education was seen as a possibility of implementing care. This measure was suggested by employees and had great adherence of the teams. Another suggestion was the development of an inclusive routine, in which family members and companions can share the care provided.

The strategies associated with ambience refer to the promotion of more interactive, inclusive and care spaces. Therefore, these spaces should value subjectivity and enhance the role of professionals, patients, and family members. Employees envisioned the hospital as a space that promotes health through activities that value the daily and human relationships. A vegetable garden, family strolls in the outside area and musical moments stimulate the inclusion of family members and the expression of personal skills and desires, promoting people's autonomy.

Prior to implementation, the consent of local managers and heads of each work unit was requested, so that the intervention process could be constructive and participatory. The details of the strategies related to Care and Ambience will be described below, and are shown below in Figure 1.

\section{Care: Is it Possible to be the Difference And MAKe A Difference?}

In relation to reception, six strategies were suggested and implemented: continuing health education with a focus on humanization; creation of a routine of information for the companions of patients undergoing surgery; expansion of strolls for inpatients outside the hospital; celebration of festive days with patients; celebration of employees' birthdays; and workplace gymnastics for employees.
In the perception of the employees, the humanization process should start by socialization and deepening of concepts previously discussed in conversation circles. In this direction, continuing health education was pointed out as a humanization strategy based on the problematization of themes and with a view to raising awareness among professionals for the (re)signification of work dynamics, as follows:

I understand that all the colleagues need to be aware of what is happening and of where we want to go with this work. Everyone, from hospitalization to bygiene, needs to know what is happening (P2).

All professionals need to know, including reception, administration, finances, nutrition, bygiene, all who are part of the work team, so they can better welcome the family member and the patient and they can know how to give proper guidance. They can't place the responsibility on someone else, saying they don't know, that their colleague is the one who knows (P9).

In this direction, continuing health education was organized based on a prospective movement called "HumanizaCHICO". For this, a layout with the image of São Francisco de Assis (patron of the hospital) was developed, seeking to expand the possibilities of interaction and enhance the movement of (re)signification of the practice. In addition, employees received personalized T-shirts with the "HumanizaCHICO" layout, allowing the process to multiply among those involved.

The schedule of the awareness-raising meetings was organized to favor the three shifts of work and all sectors of hospitalization and support of the hospital. With this focus, 18 rounds of conversation were held, with the participation of 55 collaborators, including nurses, doctors, nursing technicians, secretaries, hygiene assistants, kitchen assistants, and cooks.

Continuing health education activities started with the presentation of a video related to the different perceptions and feelings present in the hospital environment, with a special focus on empathy. Then, the different faces of hospital humanization and how to translate them into practice were discussed. At the end of each meeting, the teams were invited to record a video, with brief reports of professional experiences related to the concepts developed, which could be recorded at that time, or sent later to the researchers.
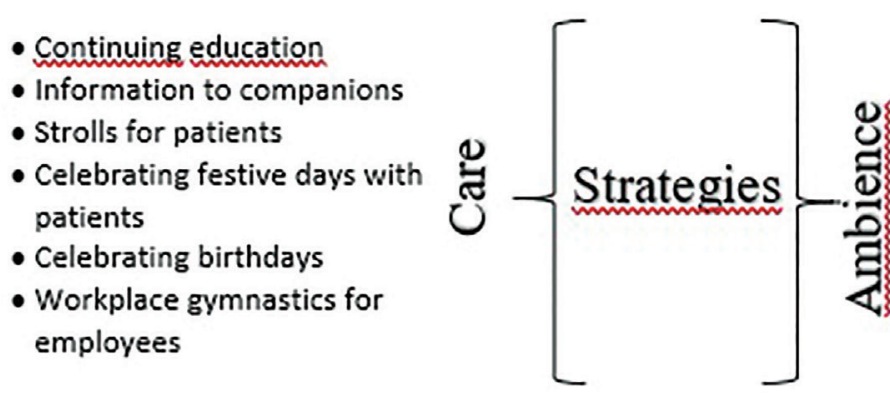

- Music therapy

- Revitalization of the break room

- Organization of a multipurpose space

- Ludic paintings in the psychiatric unit

- Vegetable garden as an occupational activity

- Television in the intensive unit

Figure 1 - Strategies related to Care and Hospital Environment. 
The end of this strategy was in a fraternization carried out in partnership with the hospital, celebrating the Nursing Week. An afternoon coffee meeting with thematic decoration and a comfortable atmosphere was organized, and directors, managers, chiefs, and employees were present. At this moment, a video on hospital humanization, composed of the reports from the continuing education meetings, was presented.

The development of a routine of information for the companions of patients undergoing surgery was suggested because, in the perception of the collaborators, the information provided to the companions must be periodic, objective and clear, which is different from what currently happens in practice. They also understand that doctors have an important role in this process and that they deserve to be actively involved in this interactive dynamic, as follows:

Usually, the information is only provided at the beginning and at the end of the surgery, that is, only when the patient enters the OR and then only when they leave (P4).

Sometimes a family member asks and they don't know how to inform. The waiting room of the surgery unit needs to be more care, reassuring family members during the surgery, not just at the beginning and at the end. The doctor must provide more detailed information, but it doesn't hurt if any other professional reaches out to the relative to give them an update on the process (P9).

The routine of information to the companions during the surgery of patients will be implemented by the local managers after they finish restructuring the Surgical Unit, currently under renovation.

Still regarding the inclusion of family members/ companions in the treatment of patients, the expansion of strolls in the external area of the hospital, preferably taking place among employees, family members and patients, was another suggestion. This strategy was widely discussed, with the participation of all interested parties, because it is practiced in some units and the employees who already carry out this measure presented reports on the observed clinical benefits. It is noticed that the hospital's external environment, coupled with the appreciation of family relationships in care contributes to the expansion of the possibilities of interaction and is a step towards a more humanized therapeutic care, as follows:

One thing that I think is nice for the user, which we have been doing, are the walks in the courtyard, including not only the nursing staff, but also the family. This is a very good thing, it seems that everything gets better (P2).

The joy it was! The son, the grandson, all of them together in the walk in the courtyard. It was so good for her, she was so happy. They even get better in the clinic, they have an important improvement. In here, it would be the case of the ICU, because in psychiatry you already do this (P9).

The implementation of external strolls requires the approval of the managers and chiefs of units, who must make routines more flexible and expand the perspectives of health care. In this sense, this strategy was promoted by the direct chiefs of the hospital units and occurred through the participation of the professionals who were already aware.

The celebration of festive days with patients was highlighted by the participants, as this can make care more care and less focused on assistance only. Employees are betting on the interactive and therapeutic potential of celebrations which, in addition to strengthening bonds, favor the social reintegration of all those involved.

I bet on the festive days, the interaction between employees, patients and family. We can always do something ludic, just like we used to do at the June party and was so good. It's already bad that the patient is spending Christmas in a hospital. And then, you know, not having anything, like, a symbol, showing that it is Christmas, a garland or something. Why not change that? (P7).

But as I am saying, it must occur at various times of the year, so the patient is not so displaced from their social life, from what happens outside the hospital (P8).

The institution studied already has a Hospital Humanization Commission, composed of different employees, which carries out festive and charitable activities. But the idea is that patients and companions are included in the process of planning and implementing collective actions. The study participants recognize that enhancing collective actions will enable a greater bond between the professional and the user and increase the quality of the patient's clinical treatment.

In addition to the celebrations with patients, celebrations with workers have been suggested and will be expanded. Birthdays of employees were already celebrated monthly, however, the practice has weakened over time. The idea of expanding and strengthening this practice was emphasized by everyone, as it is believed that it would enable a systemic view and favor a comprehensive work process.

The birthdays of the workers are important. This is the only time of the year that everyone has contact with the administration personnel. Every month there was a date and everybody who celebrated their birthdays that month were invited to have breakfast together. And the direction, the administration was there too (P11).

In dialogue and in agreement with the direction of the Hospital, this monthly activity to celebrate the employees' birthdays will be resumed and improved.

Aiming to promote health and make the work routine more flexible, the participants suggested "Workplace gymnastics" as a possibility for the humanization of professional relationships. Two employees reported positive perceptions of the inclusion of this practice in some workplaces, in which there was an improvement in the quality of life of the professionals.

Work gymnastics are great. Even if it is for 5 minutes, 10 minutes. Even if it is just one day in each unit (P4). 
For example, we can partner with undergraduate courses, such as Occupational Therapy and Physical Therapy. I can put together a scheme to have these gymnastics (9).

In this sense, an Occupational Therapy Course was contacted and promptly accepted the partnership and is already providing occupational gymnastics to employees weekly, in each of the work units that make up the hospital.

\section{AMBIENCE: IS IT POSSIBLE TO IMAGINE A HOSPITAL WITH} MUSIC, LUDIC PAINTINGS AND A VEGETABLE GARDEN?

in relation to ambience, six other strategies were identified and implemented, namely: music therapy, revitalization of the employees' break room, organization of a multipurpose space, ludic paintings in the external area of the psychiatric unit, vegetable garden as an occupational activity for patients and television in the Intensive Care Unit.

Music therapy was considered by all study participants as an alternative therapeutic tool related to ambience. It was emphasized that patients should be allowed to choose the music, which can promote their autonomy in the therapeutic process.

Music therapy is a peaceful moment for the patient, but they should be allowed to make their choices. Our patient likes southern music. And at the carnival, we did the carnival as she liked (P2).

Because they will hear what brings good feelings to them, right? It is no use for us to predetermine the music they will listen to, we should pay attention to their wishes (P9).

In this sense, each hospital unit received a portable device to tune in to radio stations or use digital media. Teams were instructed about its use and its availability to patients.

The revitalization of the employees' break room was identified as an intervention strategy towards ambience, because, in their speeches, the study participants mentioned difficulties related to acoustics, thermal and aesthetic comfort, and unfavorable care conditions. They recognize that rest is essential for the proper performance of professional activities, especially in hospital environments.

We discussed the condition of the environment for us technicians. We go there mainly on the weekend and specially the boys who come from another job are really tired. It is a good place to rest, it has plenty of space to settle and everything. But it leaves a lot to be desired in sound comfort, you cannot rest due to the noise (P12).

The revitalization of the employee's room occurred in a participatory way, through joint work between researchers, collaborators and with the special intervention of an artist who was in the institution at the time of implementation. The walls were repaints, the windows were protected with mosquito nets, and, to alleviate the discomfort reported, the rest room was divided into two environments.

In half of the rest room, which was the resting space, beds with new upholstery and shelves to keep personal items were installed. The other half of the environment was organized as a living room, furnished with the donation of a new couch and ottomans, installation of decorative pictures with motivational messages, and a painting of the HumanizaCHICO layout, done voluntarily by the patient artist.

Continuing the expansion of spaces for social interaction, the organization of a multipurpose space emerged through the reports of employees, who realize the importance of celebrating patients' birthdays in their own space. In addition, they suggested the use of the multipurpose space for children who visit psychiatric patients, especially on rainy days, and by the teams for the socialization of professional experiences.

And there was this time that a relative wanted to celebrate the birthday of a girl who was hospitalized and there was no suitable place for this purpose (P5).

When the patients' children come and it is raining there is nowhere to take them. And you cannot bring them into the psychiatric unit, we do not have a space for this (P18).

The multipurpose space was implemented by the hospital's local managers, during the study, with the adaptation of a room that was not in use. Throughout this period, celebratory events have been held, such as patients' birthdays, an employee's baby shower, continuing education activities, among others.

In the perspective of providing a care and interactive ambience for people who are in the hospital, one suggestion was to create ludic paintings on the sidewalk that gives access to the psychiatric unit. It should be noted that the place is already used by patients at sometimes and, therefore, the suggestion was to paint a hiking trail to strengthen healthy habits among patients and family members.

The painting of this front space is stimulating for the family member who comes over in the weekend. Sometimes they are allowed to receive their younger children and play with them in this front space. It is already a way for the family to play with them and get better, right? (P14).

After dialogue and negotiation with the hospital management, it was understood that the space indicated would not be adequate due to the proximity to a parking lot. But, after analysis and discussion, the managers agreed on doing ludic paintings in the inner courtyard of psychiatry. Thus, through a partnership with students of the nursing course in their internship period, it was possible to paint a hiking trail, with marks at every three meters, and a hopscotch.

In order to provide spaces for interaction that valued subjectivities, the organization of a vegetable garden for carrying out occupational activities with patients was pointed out as an intervention strategy. The participants envisioned the development of the vegetable garden in the psychiatric courtyard, in an area with an access gate to the other units, so that patients who wished and were in conditions could participate in occupational activities. The employees highlighted the importance of this activity for the integration and (re)socialization of the patient. 
There was already a vegetable garden back here. We know that it was already done and that it didn't work in the past. But this was in the past, right? Now the new staff wants to do it and so do the patients. There is good soil, I think we have to do this gardening. They plant a plant and take care of it, then when the family member arrives, they will want to show the plant they are taking care of. It is a therapy for all of them (P17).

The vegetable garden was constructed through the collective work of researchers, employees, psychology students and psychiatry patients. Campaigns and partnerships with local supporters were carried out for the acquisition of tools, plant seedlings, tires, paints and brushes. After obtaining the supplies, the tires that made up the plant beds were prepared in workshops held with the patients. This process was highly participative and integrated all those involved. The garden is being maintained by inpatients, family members and employees in periodic therapeutic activity.

Still aiming to make the environment of the Intensive Care Unit more interactive, attractive, and therapeutic to patients, the installation of televisions was proposed by the collaborators.

Then, for ambience, I think that now, as we will go to the new Intensive Care Unit, we can provide a television to those who stay in the hospital for a longer time. Up there it should work, right? Down there it doesn't work because it's bidden (P13).

This proposal was accepted by the managers, but they requested that it is done only in the new facilities, which are in the final phase. The possibility of each patient bringing their own television, if they wished, was also discussed.

\section{DISCUSSION}

The results obtained from the dialogue between researchers and study participants show that humanization, care and ambience go far beyond the renovation of structural aspects and dialogue restricted to labor issues. In addition to isolated and routine actions, it is necessary to promote new ways of being and living among the subjects involved in care, through care relational processes. It is necessary to (re)think professional attitudes and behaviors, stiffened by repetitive and mechanic actions. Respect for the uniqueness and dignity of the human being who is hospitalized goes beyond isolated and routine care. This process requires an understanding of the human being in their unique and multidimensional dimensions.

Under this focus, humanization requires an expanded and contextualized perception of health care. This care needs to be based on knowledge shared with a multidisciplinary team and involve continuing education and the work environment as support for employees, users and family members. Humanization transcends the technical dimension of care and reaches the human being, as a social subject, according to their life story ${ }^{(8)}$. The emphasis on the provision of the information needed by the companions during the surgery of the patient contributes to care, as it is related to the feedback on the impact of care interventions and facilitates communication.

For the humanization process to result in concrete changes in daily practices, this study showed that the actors must actively participate in its construction, considering that humanization can be represented by gestures and expressions such as "good morning", "thank you", "can I help you?". Therefore, humanization is present in the valuation of initiatives, in the enhancement of professional talents, in the recognition of the results achieved and in the dialogue, interaction, and communication between professionals, users and family members ${ }^{(9-10)}$.

Through interpersonal communication and dialogue with different professionals and actors in health care, the unique needs, that is, their way of being, thinking and dynamizing the work process, based on interdisciplinary collaborations, can be understood ${ }^{(11-12)}$. In this relationship, the principles of humanization value the dignity of the human being and guarantee their privacy, rights, and singular needs, including their families' needs. For family members, care involves attitudes such as being recognized by their name, receiving demonstrations of affection, such as smiles, and having someone offering to listen and resolve their needs. In contrast, family members consider as little humanized attitudes resulting from inadequate communication feel devalued when a bond is not established ${ }^{(2,13)}$.

The expansion of strolls with users in the external area is an ethical concern that demonstrates commitment, responsibility, and involvement. In this sense, the development of the professionals' interactive and associative skills should be encouraged, as the care strategies are based on the bond between those involved in the health processes. However, it is necessary to understand that care strategies occur between two people with different histories, feelings and expectations, who are interacting for a common purpose. The practice of care in health services is very difficult at times, considering that in order to welcome, one must feel welcomed in their own uniqueness ${ }^{(14-15)}$.

The celebration of festive day, music therapy and the creation of a multipurpose space, through collective actions, can contribute to the production of care for users, as, under this perspective, care is not reduced to a specific space or place, but demonstrated in human attitudes and behaviors. Under this approach, care does not depend on specific resources; it occurs in shared initiatives, knowledge and professional practices. Therefore, it represents a dynamic and permanent process of being and doing in the daily work $^{(16)}$. For this, managers must remain attentive to the needs of professionals, as human beings, offering means for them to feel human among humans. The incentive for professionals to humanize daily practices is not sufficient without the humanization of relationships and of the work environment ${ }^{(17)}$.

The celebration of employees' birthdays, the revitalization of the break room, and workplace gymnastics can be important tools for the humanization of relationships, as 
they increase social support among employees, including managers. Social support promotes healthy emotional and supportive relationships between professionals, contributing to job satisfaction.

Job satisfaction is influenced by the quality of the hospital environment. In this perspective, ambience can harmonize work relationships so that they are functional and promote pleasurable experiences, through the elements of lighting, acoustics, decoration, and external landscaping. However, it is common for health services to prioritize other issues to the detriment of ambience recommendations, as they still have the wrong idea that the qualification of spaces costs too much $^{(18-21)}$.

\section{CONCLUSION}

Care and ambience, with a view to hospital humanization, include the implementation of strategies designed with the responsible and multiplying participation of all actors (professionals and users) of the hospital. It is important that, in this process, everyone feels they are protagonists of new ways of being, living and doing in health.

In conclusion, promoting hospital humanization involves collaborative and interactional processes that includes the direction, the employees, and the patients of the institution. Humanization also requires that managers promote qualified and attentive listening to the unique needs of professionals, offering them the means to feel human among humans.

\section{RESUMO}

Objetivo: Identificar e implementar estratégias de acolhimento e ambiência, com vistas à humanização hospitalar. Método: Pesquisaação, cujo processo de investigação ocorreu entre janeiro e março de 2019, com a participação de colaboradores, advindos de funções estratégicas de um hospital de médio porte, mediante grupo focal e análise focal estratégica. O processo de implementação das estratégias de acolhimento e ambiência ocorreu a partir de maio de 2019 e permanece em andamento com a participação responsável e multiplicadora de profissionais e pacientes. Resultados: Participaram 18 colaboradores. Demostra-se que processos investigativos acompanhados de intervenções práticas, especialmente os relacionados à promoção de espaços interativos, inclusivos, acolhedores, e a criação de ambiência lúdica, atraente e associativa favorecem a atuação multiprofissional, mobilizam saberes e práticas inovadoras e contribuem para a (re)significação do ser e fazer profissional em saúde. Conclusão: $O$ acolhimento e a ambiência, com vistas à humanização hospitalar, perpassam pela implementação de estratégias concebidas com a participação responsável e multiplicadora de todos os atores (profissionais e usuários) do hospital. É importante, nesse processo, que todos se sintam protagonistas de novos modos de ser, conviver e fazer em saúde.

\section{DESCRITORES}

Hospitalização; Acolhimento; Humanização da Assistência; Ambiente de Instituições de Saúde; Relações Profissional-Paciente; Saúde do Trabalhador.

\section{RESUMEN}

Objetivo: Identificar e implementar estrategias de acogida y ambientación, con miras a la humanización hospitalaria. Método: Se trata de una investigación-acción, cuyo proceso transcurrió entre enero y marzo de 2019 con la participación de colaboradores, de funciones estratégicas en un hospital de porte mediano, mediante grupo focal y análisis focal estratégico. El proceso de implantación de las estrategias de acogida y ambientación comenzó en mayo de 2019 y sigue en marcha con la participación responsable y multiplicadora de profesionales y pacientes. Resultados: Participaron 18 colaboradores. Es evidente que los procesos de investigación, acompañados de intervenciones prácticas, principalmente las relacionadas con la promoción de espacios interactivos, inclusivos y acogedores y la creación de un ambiente lúdico, atractivo y asociativo, favorecen el desempeño multiprofesional, movilizan saberes y prácticas innovadoras y contribuyen al (re)significado del ser y del hacer del profesional en salud. Conclusión: La acogida y la ambientación enfocadas en la humanización del hospital, pasan por la aplicación de estrategias concebidas con la participación responsable y multiplicadora de todos los actores (profesionales y usuarios) del hospital. En este proceso, es importante que todos se sientan protagonistas de nuevas formas de ser, vivir y hacer en salud.

\section{DESCRIPTORES}

Hospitalización; Acogimiento; Humanización de la Atención; Ambiente de Instituciones de Salud; Relaciones Profesional-Paciente; Salud Laboral.

\section{REFERENCES}

1. Brasil. Ministério da Saúde; Secretaria de Assistência à Saúde. Programa Nacional de Humanização da Assistência Hospitalar. Brasília; 2001.

2. Oliveira K, Duarte K, Fernandes APNL. A humanização da assistência de enfermagem na clínica pediátrica. Temas Educ Saúde. $2017 ; 7$. https://doi.org/10.26673/tes.v7i0.9555

3. Pasche DF, Passos E, Hennington EA. Cinco anos da Política Nacional de Humanização: trajetória de uma política pública. Ciênc Saúde Coletiva. 2011;16(11):4541-8. http://dx.doi.org/10.1590/S1413-81232011001200027

4. Brasil. Ministério da Saúde; Secretaria de Atenção à Saúde. Política Nacional de Humanização da Atenção e Gestão do SUS. Gestão participativa e cogestão. Brasília; 2009.

5. Brasil. Ministério da Saúde; Secretaria de Atenção à Saúde. Política Nacional de Humanização. Formação e Intervenção. Brasília; 2010.

6. Brasil. Ministério da Saúde; Secretaria de Atenção à Saúde, Departamento de Ações Programáticas e Estratégicas. Atenção hospitalar. Brasília; 2011.

7. Backes DS, Colomé JS, Erdmann RH, Lunardi VL. Grupo focal como técnica de coleta e análise de dados em pesquisas qualitativas. Mundo Saúde. 2011;35(4):438-42. 
8. Sena RR, Grillo MJC, Pereira LA, Belga SMMF, França BD, Freitas CP. Educação permanente nos serviços de saúde: atividades educativas desenvolvidas no estado de Minas Gerais, Brasil. Rev Gaúcha Enferm. 2017;38(2):e64031. http://dx.doi.org/10.1590/19831447.2017.02.64031

9. Pinheiro GEW, Azambuja MS, Bonamigo AW. Facilidades e dificuldades vivenciadas na educação permanente em saúde, na Estratégia Saúde da Família. Saúde Debate. 2018;42(n. esp. 4):187-97. http://dx.doi.org/10.1590/0103-11042018s415

10. Silva KL, França BD, Marques RC, Matos JAV. Análise dos discursos referentes à educação permanente em saúde no Brasil (1970 a 2005). Trab Educ Saúde. 2019;17(2):e0019222. http://dx.doi.org/10.1590/1981-7746-sol00192

11. Silva MJP. Comunicação tem remédio: a comunicação nas relações interpessoais em saúde. $8^{a}$ ed. São Paulo: Loyola; 2011.

12. Hannawa AF, García-Jiménez L, Candrian C, Rossmann C, Schulz PJ. Identifying the field of health communication. J Health Commun. 2015;20(5):521-30. https://doi.org/10.1080/10810730.2014.999891

13. Feron LF, Caregnato RCA, Costa MR. Humanização na Terapia Intensiva: percepção do familiar e do profissional de saúde. Rev Bras Enferm. 2017;70(5):1040-47. http://dx.doi.org/10.1590/0034-7167-2016-0281

14. Lopes AS, Vilar RLA, Melo RHV, França RCS. O acolhimento na Atenção Básica em saúde: relações de reciprocidade entre trabalhadores e usuários. Saúde Debate. 2015;39(104):114-23. http://dx.doi.org/10.1590/0103-110420151040563

15. Romanini M, Guareschi PA, Roso A. O conceito de acolhimento em ato: reflexões a partir dos encontros com usuários e profissionais da rede. Saúde Debate. 2017;41(113):486-99. http://dx.doi.org/10.1590/0103-1104201711311

16. Pereira AD, Freitas HMB, Ferreira CLL, Marchiori MRCT, Souza MHT, Backes DS. Atentando para as singularidades humanas na atenção à saúde por meio do diálogo e acolhimento. Rev Gaúcha Enferm. 2010;31(1):55-61. https://doi.org/10.1590/S1983-14472010000100008

17. Dodou HD, Sousa AAS, Barbosa EMG, Rodrigues DP. Sala de parto: condições de trabalho e humanização da assistência. Cad Saúde Coletiva. 2017;25(3)332-8. http://dx.doi.org/10.1590/1414-462x201700030082

18. Ribeiro RP, Marziale MHP, Martins JT, Galdino MJQ, Ribeiro PHV. Estresse ocupacional entre trabalhadores de saúde de um hospital universitário. Rev Gaúcha Enferm. 2018;39:e65127. http://dx.doi.org/10.1590/1983-1447.2018.65127

19. Ferri A, Ribeiro J, Paixão D. Qualidade de vida no trabalho dos profissionais de enfermagem em ambiente hospitalar: uma revisão integrativa. Esp Saúde. 2015;16(1):66-74. https://doi.org/10.22421/1517-7130.2015v16n1p66

20. Ribeiro JP, Gomes GC, Thofehrn MB. Health facility environment as humanization strategy care in the Pediatric Unit: systematic review. Rev Esc Enferm USP. 2014;48(3):530-9. http://dx.doi.org/10.1590/S0080-623420140000300020

21. Sato M, Ayres JRCM. Arte e humanização das práticas de saúde em uma Unidade Básica. Interface (Botucatu). 2015;19(55):1027-38. https://doi.org/10.1590/1807-57622014.0408 